\title{
A (trans)national emotional community? Greek political songs and the politicisation of Greek migrants in West Germany in the 1960s and early 1970s
}

\author{
Nikolaos Papadogiannis, Department of History, Humboldt University of Berlin, \\ Unter den Linden 6, 10099 Berlin, npapadogian@gmail.com
}

\section{Short CV}

Nikolaos Papadogiannis obtained his PhD in History from the University of Cambridge in 2010 (supervisor: Adam Tooze; external examiner: Mark Mazower). Since January 2012 he has been a postdoctoral researcher, examining the making of young West German and Greek tourists in the 1960s and the 1970s, at the Humboldt University of Berlin. He is sponsored by the Alexander von Humboldt Foundation. He has published on issues related to left-wing cultural politics, gender, mass consumption and youth cultures in international academic journals, such as the European History Quarterly and the Journal of Modern Greek Studies. He has co-edited a thematic unit in the European Review as well as a thematic issue in the European Review of History (forthcoming).

\footnotetext{
Abstract

This article examines the emotional standards and experiences connected with the entehno laiko music composed by Mikis Theodorakis that was immensely popular among left-wing Greek migrants, workers and students, living in West Germany in the 1960s and the early 1970s. Expanding on a body of literature that explores the transnational dimensions of protest movements in the 1960s and the 1970s, the article demonstrates that these transnational dimensions were not mutually exclusive with the fact that at least some of those protestors felt that they belonged to a particular nation. Drawing on the conceptual framework put forth by Barbara Rosenwein, it argues that the performance of those songs was conducive to the making of a (trans)national emotional community. On the one hand, initially for Greek left-wingers and, after 1967, also for Greek centrists, who resided in West Germany, collective singing of music composed by Theodorakis served as a means of 'overcoming fear' and forging committed militants who struggled for the social and political transformation of their country
} 
of origin. On the other, from the late 1960s onwards those migrants increasingly enacted this emotional community with local activists from West Germany as well.

Keywords: migration, music, emotions, emotional communities

In 1968, Elan, the magazine of the radical West German left-wing organisation SDAJ [Sozialistische Deutsche Arbeiterjugend, Socialist German Workers' Youth], which was established in 1968 and treated the German Democratic Republic (GDR) as its role-model, published an interview with some left-wing Greek artists. Those included Maria Farantouri, who collaborated closely with the composer Mikis Theodorakis. The latter, also a prominent left-winger, was persecuted by the dictatorial regime that ruled Greece at that point, as discussed below in detail. Farantouri performed onstage in various locations across the globe, presenting music composed by Theodorakis. According to her, in Moscow people were crying during the concert, while in the Federal Republic of Germany they demonstrated their enthusiasm. ${ }^{1}$

To understand the historical place of the interview, we need to place it in the context of both the situation in Greece and the transnational protests around 1968. The establishment of the dictatorship in Greece one year prior to the publication of this interview had marked a turning point for Greek left-wingers, both those residing in

This article is linked with my postdoctoral project, which is funded by the Alexander von Humboldt Foundation. I would like to thank Thomas Mergel, Maren Möhring, Regina Römhild, Manuela Bojadžijev, Evthymios Papataxiarchis, Vassilis Tsianos and Miltos Pechlivanos for discussing with me about ideas contained in this article. I would also like to express my gratitude to Joachim Häberlen, Russell Spinney, Josie McLellan and the two anonymous peer reviewers for their comments. Of course, I alone am responsible for the analysis and any errors herein.

1 'Sänger im Exil', elan, Feb. 1968, 23, Bibliothek, Hamburger Institut für Sozialforschung. 
Greece and the migrants. In Greece, political parties were banned, while advocates of the left often fell victim to persecution and torture. Meanwhile, Greek embassies and consulates abroad tried to monitor their activity, while simultaneously encouraging the operation of pro-regime groups.

At the same time, the interview also points to the transnational and global nature of protest cultures during the 1960s and 1970s. Diverse countries around the world were shaken by widespread protests 'around $1968^{2}$. In relevant scholarship, '1968' usually denotes a phase of change in which processes of left-wing political mobilisation outside the traditional party frameworks merged with shifts in sexual norms, often described as the 'sexual revolution'. ${ }^{3}$ In general, many of the activists that participated in the ' 1968 ' uprisings perceived their actions as indelibly linked with a 'global revolt against capitalism', while the mass media 'created transnational and intercultural linkages' between militants active in different contexts. ${ }^{4}$ In this vein, historian Martin Klimke has shown that 'media coverage' enabled West German

\footnotetext{
${ }^{2}$ Numerous scholars employ this term to show that the so-called ' 1968 ' protests started before and, in some cases, perpetuated after that year. See, for instance, the network entitled 'Around 1968. Activists, Networks and Trajectories', http://www.history.ox.ac.uk/research/project/around-1968-activismnetworks-trajectories.html (last accessed: 12 Nov. 2013).

${ }^{3}$ Radical left-wing actors that emerged in the 1960s have been labelled in scholarly debates as the "new left': some of the main characteristics of the latter were the critique of bureaucratic structures; the scepticism towards the 'working class' as a revolutionary subject; and the endorsement of provocative action which the left had previously avoided. About the so-called 'new left', see, for instance, GerdRainer Horn, The Spirit of '68. Rebellion in Western Europe and North America, 1956-1976 (Oxford: Oxford University Press), 131-177.

${ }^{4}$ Carole Fink, Philipp Gassert, Detlef Junker, 'Introduction', in Carole Fink, Philipp Gassert and Detlef Junker, eds., 1968. The World Transformed (German Historical Institute, Washington D.C.: Cambridge University Press, 1998), 1-28, here 2-3.
} 
protestors to 'familiarise themselves with the actions of their American peers'. ${ }^{5}$ In addition, historian Kostis Kornetis suggests that migration from southern to northern Europe in the postwar decades constituted one more 'transnational channel' that accommodated cultural transfers, such as the music of Pink Floyd, among protestors in diverse countries in northern and southern Europe at that point. ${ }^{6}$ Such transnational co-operation was not necessarily peculiar to protest movements of the late 1960s: For instance, historian Kristina Schulz convincingly argues that the circulation of feminist ideas in the early 1970 s was 'international'?

Were then national boundaries of no significance at all for those subjects? This would be an erroneous assumption, as this article will demonstrate. To this end, it analyses the circulation of Greek political songs among, among and beyond militant Greek migrants residing in the Federal Republic of Germany in the 1960s and early 1970s. It focuses on Greek migrants in West Germany, because they have hitherto received scant scholarly attention. ${ }^{8}$ The article argues that the spread of such songs

${ }^{5}$ Martin Klimke, The Other Alliance: Student Protest in West Germany and the United States in the Global Sixties (Princeton: Princeton University Press, 2011), 53.

${ }^{6}$ Kostis Kornetis, “"Everything Links"? Temporality, Territoriality and Cultural Transfer in the '68 Protest Movements', Historein 9 (2009), 34-45.

${ }^{7}$ Kristina Schulz, 'Echoes of Provocation: 1968 and the Women's Movements in France and Germany', in Gerd-Rainer Horn and Padraic Kenney, eds., Transnational Moments of Change, Europe 1945, 1968, 1989 (Oxford: Rowman and Littlefield, 2004), 137-154.

${ }^{8}$ Perhaps the only relatively well-researched issue concerning Greek migrants in the Federal Republic of Germany is that of their education, see Dieter Hopf, Herkunft und Schulbesuch ausländischer Kinder (Berlin: Max-Planck-Institut für Bildungsforschung, 1987). One of the very few analyses of the performance(s) of music by Greeks residing in Germany is Gerasimos Alexatos, 'Xairete: Ein griechisches Armeekorps in Görlitz', in Wolfgang Schultheiß and Evangelos Chrysos, eds., Meilensteine deutsch-griechischer Beziehungen (Athens: Stiftung für Parlamentarismus und 
helped shape a (trans)national condition. These songs were jointly performed by Greek as well as other left-wing migrants and locals residing in West Germany. At the same time, at least in the case of Greek activists, their performance did not preclude a sense of national identification. ${ }^{9}$ Greek migrant political activity was therefore marked by the 'condition of simultaneity': the bonds they felt with their country of origin did not prevent them from developing links with locals. ${ }^{10}$ This vacillation between the transnational and the national was particularly associated with the perspective of the struggle of those militants, who viewed developments in their countries of origin as linked with international ones.

Collectively listening to and singing these songs was a key practice, this article argues, for enacting multiple emotional communities. Emotional communities are, according to Rosenwein, 'social groups whose members adhere to the same

Demokratie des Hellenischen Parlaments, 2010), 185-199. Manuel Gogos provides a brief overview of the history of Greek migrants in West Germany in the second half of the 20th century in general, which, however, contains little information on their musical taste, see Manuel Gogos, 'Big Fat Greek. Versuch über die griechische Diaspora in Deutschland', in: Institut für Kulturpolitik, ed., Beheimatung durch Kultur. Kulturorte als Lernorte interkultureller Kompetenz, Essen 2007, 180-188.

${ }^{9}$ On the role of music in protest movements, see Ron Eyerman and Andrew Jamison, Music and Social Movements. Mobilising Traditions in the Twentieth Century (Cambridge: Cambridge University Press, 1998); Christophe Traïni, La Musique en colère (Paris: Presses de Sciences Po, 2008). While Eyerman and Jamison focus on lyrics, I wish to explore the emotional impact of the performance of those songs as well.

${ }^{10}$ On the concept of the 'condition of simultaneity', see Peggy Levitt and Nina Glick-Schiller, 'Conceptualising Simultaneity: A Transnational Social Field Perspective on Society', International Migration Review 38, 145 (2004), 1002-1039, here1003. 
valuations of emotions and their expression'. ${ }^{11}$ Drawing on her suggestion, the article explores the music performed, the spaces where this happened, and the gender and national identification of those involved. It examines the emotions that were 'privileged' and 'denigrated' by Greek left-wing activists and the performances through which this was achieved.

Making use of a variety of sources, such as texts published by Greek left-wing organisations and by the Greek associations in West Germany in the 1960s and the early 1970s as well as oral history interviews I conducted, the article will proceed in five steps: First, it analyses a range of overlapping emotional communities, in which first-generation Greek migrants in West Germany were involved. The expression of 'suffering' was one of their defining features, which was often achieved through listening and singing Greek folk and popular music. The article proceeds to follow on the development of one of those communities, formed by Greek left-wing migrants, in the early-to-mid 1960s. What set this emotional community apart was the effort to transform 'suffering' into 'dedication to struggle', usually through events that combined Greek folk music and dance with the collective singing of Greek political songs. Subsequently, it outlines some important ruptures, namely the establishment of the dictatorial regime in Greece in 1967 and the widespread protests 'around 1968' in

${ }^{11}$ On 'emotional communities', see: Barbara Rosenwein, 'Problems and Methods in the History of Emotions', Passions in Context: Journal of the History and Philosophy of the Emotions 1, 1 (2010), online at: http://www.passionsincontext.de/index.php?id=557, 11. See also: Barbara Rosenwein, Emotional Communities in the Early Middle Ages (Ithaca: Cornell University Press, 2006); Barbara Rosenwein, Nicole Eustace, Eugenia Lean, Julie Livingston, Jan Plamper, and William M. Reddy, AHR Conversation, 'The Historical Study of Emotions', American Historical Review 117.4 (2012), 1467-1511. On interpreting music in its social context, see Evelyn Payne Hatcher, Art as Culture: An Introduction to the Anthropology of Art (Westport, CT: Bergin and Garvey, 1999), 1-20. 
West Germany, which led to transformations in the political activity of Greek migrants there. The article shows that some of those changes were reflected in the shifting enactment of the emotional community of Greek left-wing migrants, which extended to encompass non-left-wing opponents of the Greek dictatorship. Similarly, it indicates that Greek political songs increasingly functioned from that point onwards as a means of establishing affective bonds between left-wing locals and migrants. I demonstrate that the (trans)national orientation of the militants under study was reinforced in the enactment of a porous emotional community, which was simultaneously national and transnational. Thus, I concur with scholars who claim that such communities may cut across distinctions of nationality. ${ }^{12}$

\section{Singing their emotions: Greek migrants in West Germany}

The mobility of people from southern to northern Europe marked the postwar history of the continent for decades. Various countries, such as West Germany, Sweden and Switzerland, developed massive foreign labour recruitment programmes. ${ }^{13}$ According to the agreements signed by the West German government with countries such as Italy (1955), Greece (1960), Spain (1960), and Turkey (1961), incoming migrant workers were only supposed to temporarily reside in West Germany, as long as they worked for a German company. ${ }^{14}$ Henceforth, the number of migrants moving to West Germany from southern Europe increased substantially. Between 1961 and 1973, when the oil crisis put an end to foreign labour recruitment, the number of

\footnotetext{
${ }^{12}$ See, for instance: Benno Gammerl, 'Emotional styles- concepts and practices', Rethinking History: The Journal of Theory and Practice 16.2 (2012), 163f.

${ }^{13}$ Rita Chin, The Guest Worker Question in Postwar Germany (Cambridge: Cambridge University Press, 2007), 24-29.

${ }^{14}$ Ibid, 3 .
} 
Greek residents in Germany had risen from 42,000 to $408,000 .{ }^{15}$ Yet, even after the Anwerbestopp of 1973, the moratorium on foreign labour recruitment, Greeks continued to move to Germany, albeit primarily as students. ${ }^{16}$ At the same time, Greek 'guest workers' began to return to Greece, in response to the improving job market in Greece. ${ }^{17}$

These first-generation Greek migrants continued to closely identify with their country of origin and, by extension, with their compatriots in West Germany. The community of Greek migrants thereby formed in Germany can be conceptualised as an 'emotional community' which mainly revolved around a feeling of 'suffering' and its expression during the 1960s and early 1970s. Music played a key role in facilitating those affective bonds. For instance, Andreas Arnakis' bilingual radio show entitled 'Meeting in Germany', which broadcast news about Greece as well as Greek

15 Data reproduced in: Maren Möhring, Ausländische Gastronomie. Migrantische Unternehmensgründungen, nеuе Konsumorte und die Internationalisierung der Ernährung in der Bundesrepublik Deutschland (Oldenbourg: Oldenbourg Verlag, 2012), 392f.

16 Yannis Voulgaris, I Ellada tis Metapolitefsis 1974-1990. Statheri dimokratia simademeni apo ti metapolemiki Istoria (Athens: Themelio, 2002), 124f; Ilias Katsoulis, 'Demokraten gegen Obristen, Griechen in Deutschland', in Wolfgang Schultheiß and Evangelos Chrysos, eds., Meilensteine deutschgriechischer Beziehungen (Athens: Stiftung für Parlamentarismus und Demokratie des Hellenischen Parlaments, 2010), 291-298, here 291. In the oral testimonies that I have gathered, numerous Greeks who studied at German universities in the period under examination defined themselves as 'migrants'. Still, some of them found the term appropriate to describe only the condition of the so-called 'guest workers'. In this article, I employ a broad conceptualisation of the term 'migration', but the extent to which this was used by all Greeks who moved from their natal areas to West Germany in the 1960s and 1970s certainly awaits further examination.

${ }^{17}$ Panos Kazakos, Anamesa se Kratos kai Agora. Oikonomia kai oikonomiki politiki sti metapolemiki Ellada, 1944-2000 (Athens: Patakis, 2001), 320-24. 
music, apparently struck a chord among migrants. ${ }^{18}$ According to Dimitris Katsantonis, who has lived in Munich, Mannheim and Heidelberg since the 1960s and has been involved in left-wing politics ever since, it was the 'ear' through which Greek migrants 'heard' their 'motherland'. ${ }^{19}$ They listened to such shows individually or together with a few friends in apartments or their residential halls [Heime]. It was the music of Stelios Kazantzidis in particular that marked the migrant experience of many Greeks in West Germany. Elpida Domokou-Tsakiri, who migrated from northern Greece to West Germany in the early 1960s, in order to work, stressed that 'we found those songs touching'. ${ }^{20}$ Similarly, '[Greek] migration [to West Germany]', according to Katsantonis, 'is emotionally linked to Kazantzidis. [...]. On Saturday, on Sunday you walked by the residence halls, where those workers lived, and that was the only music you could hear'. ${ }^{21}$ The lyrics of those songs portrayed migration as a quintessentially miserable experience. Some of their common themes were mothers lamenting the departure of their offspring as well as the longing of migrants to return 'home'. For instance, the lyrics of the song 'To psomi tis xenitias' [The bread of foreign lands] contained the following lines: 'Please, Virgin Mary, make migration stop. No mother should cry again for being separated (from her offspring) and they should come back home again'. Notably, other emotions were also associated with this suffering and 'pain' [ponos], such as the 'fear' [fovos] migrants felt facing

\footnotetext{
${ }^{18}$ Interview with Aspasia Frangou, 27 Mar. 2013. She was an EKKE member and student in West Berlin in the early 1970s; interview with Dimitris Katsantonis, 17 Feb. 2013. Most of the names of the interviewees are pseudonyms. Arnakis' short biographical note is also available in his book: Andreas Arnakis, Ta agoura verikoka (Athens: Istoriko Fotografiko Archeio Neoteris Elladas, 2012).

${ }^{19}$ Interview with Dimitris Katsantonis, 17 Feb. 2013.

${ }^{20}$ Interview with Elpida Domokou-Tsakiri, 20 May 2012.

${ }^{21}$ Interview with Dimitris Katsantonis, 17 Feb. 2013.
} 
conditions that differed substantially from their everyday life up to that point. ${ }^{22}$ Other oral testimonies stressed 'anger' [thymos] at what was depicted as the 'unequal treatment' that migrants believed they experienced in comparison to locals. ${ }^{23}$

Greek migrants not only listened to this music on the radio, but also sang such songs collectively, a practice that was arguably even more important for the formation of this emotional community. Two important locations where such performance took place were the Heime and the community halls. Greek residents of the former often met during their leisure time, as Katsantonis mentioned above, to 'sing their pain' together. ${ }^{24}$ The Gemeinden [communities] multiplied from the early 1960s onwards in cities where Greek migrants lived. Such communities were founded, for instance, in Cologne (in 1962), Frankfurt (1964), West Berlin (1964), and Munich (1964). ${ }^{25}$ They usually proclaimed in their charters that one of their main aims was to preserve Greek 'customs' and organise relevant cultural events. ${ }^{26}$ They also offered space where patrons could gather, discuss, play cards, and sing.

\footnotetext{
${ }^{22}$ Interview with Nikitas Apostolidis, 15 Oct. 2012, who has lived in West Germany since the early 1970s.

${ }^{23}$ For instance, interview with Stathis Gortynos, 28 Mar. 2013. He lived in West Germany from the mid-1960s to the mid-1970s.

${ }^{24}$ Interview with Dimitris Katsantonis, 17 Feb. 2013.

${ }^{25}$ Announcement of the creation of the Greek community in West Berlin, 17 Aug. 1964, Archive of the Forschungsstelle für Zeitgeschichte in Hamburg (hereafter FZH), Gemeinde der Griechen in Hamburg e.V. 1961-64. About the history of the Greek communities in Cologne and Frankfurt, see the information posted on their webpages: http://www.griechische-gemeinde-koeln.de/?page id=1086 and http://www.ggfu-frankfurt.de/index.php/geschichte.html , respectively (last visited: 17 Jun. 2013).

${ }^{26}$ For instance: Elliniki Koinotis Ergazomenon Kolonias kai Periochis, Katastatiko, 1962, Archive of the Greek Community in Cologne.
} 
While 'suffering' featured prominently in the formation of the emotional community of Greek migrants, the image of a coherent national emotional community revolving solely around this feeling needs to be complicated. Other emotions and emotional conditions, kefi in particular, played an important role within this community as well. The latter term is difficult to translate. It is typically rendered into English as 'fun', 'joy' or 'merriment'. Yet, as anthropologist Jane Cowan, who has studied kefi in the city of Sohos in northern Greece, remarks, 'more than just a label for a kind of high spirits, kefi has philosophical dimensions, particularly concerning the relation between self and collectivity.' ${ }^{27}$ While it 'represents the natural predisposition of the [individual] heart', it is experienced more deeply within a group of people singing and dancing. ${ }^{28}$ Kefi was a profoundly gendered emotion. Cowan and Papataxiarchis have asserted that heterosexual men were mostly involved in the performance of this emotional condition. Women were not excluded, at least in Sohos, but, in contrast with men, they were not licensed to feel kefi as a result of having consumed alcohol. In addition, while men could experience it both individually and collectively, the former was not a legitimate option for women. Keficentred performances by Greek migrants in West Germany usually included singing and dancing together to Greek folk music. Such performances served actually as a means of coping with the distance from 'motherland' and tackling with the suffering imputed on migration. Quite tellingly, Domokou-Tsakiri mentioned that such

\footnotetext{
${ }^{27}$ Jane Cowan, Dance and the Body Politic in Northern Greece (Princeton: Princeton University Press, 1990), 107.

${ }^{28}$ Ibid. See also Evthymios Papataxiarchis, 'O kosmos tou kafeneiou. Tavtotita kai antallagi ston andriko symposiasmo', in Evthymios Papataxiarchis, Theodoros Paradellis, eds., Tavtotites kai Fylo sti Synchroni Ellada (Athens: Alexandreia, 1998), 209-250, here 237.
} 
performances were among the occasions on which 'we consoled one another'. ${ }^{29}$ Other narrators used family metaphors to describe their emotional experience during those events: statements, such as 'we felt like a family', were not at all uncommon in the testimonies I have gathered.

But the 'emotional community' of Greek migrants was not internally coherent, and actually fragmented along regional lines, among others. Initially, Greek migrants who emanated from the Black Sea [Pontioi], but also from diverse areas in Greece, such as Epirus and Thessaly, gathered spontaneously in spaces, such as the rooms of the buildings where Gemeinden [communities] were hosted, to sing and dance. Gradually, they founded regional associations. Quite often, those societies attracted musicians, who played local instruments, such as the stringed one kementse (also called a Pontiaki lyra) in the case of Pontioi. ${ }^{30}$ Greek popular music, such as Kazantzidis' sorrowful songs, featured prominently at their gatherings. Texts published by those groups in the 1960s and the 1970s and the oral testimonies of participants in such events indicate that the emotional conditions of diaskedasi [entertainment] and kefi were central in these contexts. ${ }^{31}$ In the gatherings of the Pontioi, melancholy and kefi were closely intertwined: according to Nikitas

\footnotetext{
${ }^{29}$ Interview with Elpida Domokou-Tsakiri, 20 May 2012.

${ }^{30}$ About the cultural associations and networks of the Pontioi in München, see the oral testimonies collected in: Eleni Delidimitriou-Tsakmaki, Lebenswege. Zeugnisse griechischer Einwanderer in Deutschland (Thessaloniki: University Studio Press, 2005), 204.

${ }^{31}$ See for instance Enosi Pontion Amvourgou, 'Prosklisi', FZH, Gemeinde der Griechen in Hamburg e.V., 1979. Interview with Grigoris Asimatos, 30 Jul. 2013. He studied in West Berlin from the late 1960s to the mid-1970s. In general, however, there is no research on the issue whether participation in the communities and regional associations was a factor that differentiated the ways in which Greek migrants emotionally invested in the experience of migration.
} 
Apostolidis, who is a Pontios, they sang songs revolving around the frustration due to the fact that they lived away from the 'motherland' of Pontos as well as joyful ones; both emotions were amplified by the sound of the kementse. ${ }^{32}$

Another parameter that diversified the emotional communities in which Greek migrants in West Germany engaged themselves was age. Numerous university students and young workers came to appreciate cultural patterns that were core components of the youth cultures existing in West Germany and elsewhere in the 'West' at that point. Looking back, some of those students say they liked dancing to Anglo-American popular music in the 1970s, either in discotheques or at parties in private apartments. Young students of approximately the same age were able to socialise with their peers from different national backgrounds and flirt with local women. Grigoris Parakampos, who was a young worker residing in West Berlin in the 1970s, recounted that 'at parties we listened to English songs' ${ }^{33}$ For some of those migrants, especially those who originated from rural areas, this stood in stark contrast to their experience prior to migration. Apostolidis, who was a university student in West Berlin in the 1970s, referred to the limitations on the intermixing of boys and girls in his small, northern Greek village: 'we did not live as young people until we were 18-19 (...) for us who came here (in West Germany), life started' ${ }^{34}$ Those young migrants, however, did not scorn Kazantzidis' songs or Greek folk music and dances. They listened to various music genres in diverse spaces, sometimes mixing with older migrants. In those performances, they often developed conflicting understandings of 'migration': a negative one, while collectively singing Kazantzidis'

\footnotetext{
${ }^{32}$ Interview with Nikitas Apostolidis, 15 Oct. 2012.

${ }^{33}$ Interview with Grigoris Parakampos, 11 Nov. 2012.

${ }^{34}$ Interview with Nikitas Apostolidis, 15 Oct. 2012.
} 
songs, and one that imbued their leisure time in West Germany with 'joy'. Those ambiguities were particularly illuminated in their oral testimonies, which, to borrow a term used by historian Alessandro Portelli, showed the 'horizon of shared possibilities, real or imagined' those migrants entertained at that point. ${ }^{35}$

\section{'Everybody was so happy, so warm, so brotherly': The formation of the emotional community of Greek left-wing migrants}

Political affiliations also resulted in different emotional communities. Although their political activities have been neglected in relevant scholarship until recently, neither Greek nor other first-generation migrants to West Germany were apathetic. ${ }^{36}$ Already in the early-to-mid 1960s, many Greek migrants had become members or sympathisers of Greek left-wing organisations. During those years, left-wingers in Greece fell victim to diverse types of exclusion and were treated by the state as 'dangerous citizens', as anthropologist Neni Panourgia has aptly remarked. ${ }^{37}$ From the end of the civil war in 1949 until the coup d'état on 21 April 1967, although elections took place regularly, Greece experienced a limited democracy. ${ }^{38}$ The KKE

\footnotetext{
${ }^{35}$ Alessandro Portelli, The battle of Valle Giulia. Oral History and the art of dialogue (Madison: University of Wisconsin Press, 1997), 88.

${ }^{36}$ Both anthropologist Manuela Bojadžijev and historian Simon Goeke mention this lacuna in research. See Manuela Bojadžijev, Die windige Internationale. Rassismus und Kämpfe der Migration (Münster: Westfälisches Dampfboot, 2008), 12; Simon Goeke, 'The Multinational Working Class? Political Activism and Labour Migration in West Germany during the 1960s and 1970s', 160-182, here 160f.

${ }^{37}$ Neni Panourgia, Dangerous Citizens: The Greek Left and the Terror of the State (New York: Fordham University Press, 2009), 117-123.

${ }^{38}$ See, for instance, Nikos Alivizatos, Oi Politikoi Thesmoi se Krisi, 1922-1974. Opseis tis ellinikis empeirias (Athens: Themelio, 1995).
} 
[Kommounistiko Komma Elladas, Communist Party of Greece] was outlawed in 1947. Still, most Greek left-wingers participated in the EDA [Eniaia Dimokratiki Aristera, United Democratic Left], which operated legally from 1951 to 1967. Members of the clandestine KKE were for a period simultaneously affiliated with EDA. Branches of EDA and its youth groups were also established in West Germany, which were the most successful in recruiting Greek migrants in comparison to EDA branches elsewhere in Western Europe. ${ }^{39}$ Its youth organisations were the official Youth of EDA and the DKNGL [Dimokratiki Kinisi Neon Grigoris Lambrakis, i.e., the Democratic Youth Movement Grigoris Lambrakis], a group affiliated with EDA, but not guided by it. They merged in 1964, to form the DNL [Dimokratiki Neolaia Lambraki, Democratic Youth Lambrakis].

Greek left-wingers in West Germany during the 1960s and 1970s shared with the right a positive reference to the nation and similarly performed kefi to overcome the suffering of migration. Yet, in the left-wing inflection of this emotional condition, it also became a prerequisite for gaining courage [kouragio] and hope [elpida], a means of forging dedicated militants, who subscribed to the cause of the socialist transformation of Greece.

Greek left-wing groups in West Germany, such as EDA or the DNL, regularly organised celebrations. The events that mattered most for them were Christmas, New Year's Eve, and Easter, as well as the anniversaries of the War of Independence of 1821 (on March 25), the creation of the DNL, the rejection of the Italian ultimatum demanding the annexation of Greek territory in 1940 (on October 28) and the resistance against the tripartite occupation of Greece by Germany, Italy and Bulgaria

\footnotetext{
${ }^{39}$ Ioanna Papathanasiou et al., I Neolaia Lambraki ti dekaetia tou 1960 (Athens: Geniki Grammateia Neas Genias, 2009), 120.
} 
in 1941-44. Some branches of EDA and its youth groups also held frequent musical and dancing events, in Hanover, for example, once a month. ${ }^{40}$ Even at those celebrations where EDA youth branches featured prominently, older migrants were not excluded. Indeed, these events often took place in spaces such as the Gemeinde halls where people could mingle regardless of age. During such gatherings, identification with the Greek 'motherland' was celebrated. 'Inside the room, on the right, a huge Greek flag hung on the wall,' as a text by the DNL in Hanover about such a celebration stated, '(...) we had placed on almost all the walls very beautiful artefacts produced by women (...) ${ }^{41}$ Evidently, Greek left-wingers in West Germany were deeply concerned that, unless they were promoted, what they construed as national traditions might fade out, especially in the context of migration. Throughout the 1960s, the Greek left was crystal clear in criticising migration per se, as a phenomenon that deprived Greece of the skills and the labour of those workers. ${ }^{42}$ For instance, an announcement of the youth branch of EDA in Hanover referred to the 'uprooted' Greek youth residing in the city. ${ }^{43}$

Music and its emotional investment were prescribed in EDA rhetoric as a means of reinforcing Greek national identity among Greek migrants in West Germany. In those events, musicians quite often played instruments, such as the

\footnotetext{
${ }^{40}$ See, for instance, Report of the activity of DNL in Hanover, 25 Feb. 1967. ASKI, Archeio EDA, 04/11. Invitation, DKNGL Munich, 1965, ASKI, Archeio EDA, 08/00001.

41 'Paschalinos choros tis D. N. Lambraki tou Annoverou kai diagonismos ergocheirou', report, 30 Apr. 1965. ASKI, Archeio EDA, 04/11.

${ }^{42}$ See, for example, Anna Mahaira, 'Metanasteysi kai oikonomiki anaptyxi sti metapolemiki Ellada', Mnimon 25 (2003), 79-110.

${ }^{43}$ Note, DKNGL Hanover, Jan. 1965, ASKI, Archeio EDA, 04/11. In some West German cities, DKNGL continued to exist until 1965.
} 
kementse and the bouzouki, a plucked string instrument, whose sound resembles to an extent that of the mandolin. The rest of the participants engaged themselves in singing Greek folk music from diverse regions as well as in group dance. Kefi figured prominently in this regard. A report in 1965 on the celebration of Easter by the DNL in Hanover mentioned: 'Soon kefi became predominant. Everybody was so happy, so warm, so brotherly. Those living in foreign lands have their own way of celebrating their happiness, they become one, one man, one soul, one nostalgia for the motherland. ${ }^{44}$ This link between kefi and the longing for return to their country of origin or their specific birthplace permeated many oral testimonies of former EDA members. Indeed, one narrator, Gortynos, a young worker who resided in Nürnberg and Munich from the mid-1960s to the mid-1970s and was affiliated with EDA in the late 1960s, went further to argue that this emotional experience aroused many of his senses: '[When listening to this music], I could even imagine the smell [of my natal area]' ${ }^{45}$ This nostalgic conceptualisation of kefi was supposed to unite all migrants regardless of ideological background, even though the abovementioned 'one man' was not necessarily a left-winger. Similarly, its enactment followed the rules described by Cowan and Papataxiarchis, which were not peculiar to Greek left-wing migrants, but constituted common ground they shared with their compatriots.

Simultaneously, a narrower, left-wing understanding and enactment of kefi could also be observed in the same gatherings. Its distinguishing feature entailed listening to entehno laiko [artistic popular] music by Theodorakis, who was a leading figure of the Greek left at that point: he was the president of the DNL, the youth

\footnotetext{
44 'Paschalinos choros tis D. N. Lambraki tou Annoverou kai diagonismos ergocheirou', report, 30 Apr. 1965. ASKI, Archeio EDA, 04/11.

${ }^{45}$ Interview with Stathis Gortynos, 28 Mar. 2013.
} 
organisation of EDA, and was elected as an EDA member of parliament in 1964. He was the creator of that music genre, whose core component was setting poetry to 'Greek popular music'. ${ }^{46}$ Theodorakis resorted to the work of renowned Greek poets, while extensively employing the sound of the bouzouki. Various sources indicate the preponderant role that Theodorakis' compositions played in the events organised by EDA in West Germany. ${ }^{47}$ From the mid-to-late 1960s onwards, Theodorakis also inspired Greek migrant musicians, such as Kostas Papanastasiou, who at that point resided in West Berlin, was affiliated with EDA and studied architecture until 1970. He produced two albums in the 1960s and 1970s: Stavrosi 67 [Crucifixion 1967] and Parousia [Presence, 1972]. ${ }^{48}$

In the inflection of kefi, which revolved around entehno laiko composed by Mikis Theodorakis, this emotional condition did not just connote nostalgia for the country of origin, but also the dedication to contribute to its radical transformation. Quite tellingly, Gortynos stated that those songs gave left-wing Greek migrants 'power' during those years. ${ }^{49}$ Their lyrics stimulated mobilisation - and for good reason: Theodorakis' first entehno laiko work appeared in the early 1960s with the album Epitaphios, which was based on a poetic collection of the same name by Yiannis Ritsos, a Communist. It was inspired by a mother's lament for her son, who

\footnotetext{
${ }^{46}$ Dimitris Papanikolaou, Singing Poets: Popular Music and Literature in France and Greece (Oxford: Legenda, 2007), 88.

${ }^{47}$ Many texts published by EDA and its youth groups in West Germany mention events centring on Theodorakis' music. For instance: Resolution, DKNGL Hamburg, 5 Dec. 1964. ASKI, Archeio EDA, $04 / 11$.

${ }^{48}$ See the biographical note in his personal page: http://www.kostas-papanastasiou.de/ (last visited 15 Jun. 2013).

${ }^{49}$ Interview with Stathis Gortynos, 28 Mar. 2013.
} 
was killed during a labour demonstration in Thessaloniki in 1936. Theodorakis went on to compose numerous other works, such as Axion Esti (1964, a 'popular oratorio' based on Odysseas Elytis' poetry) and Romiossini (1966, Ritsos' poetry set into music), whose content refers to resistance and popular uprising. Those migrants, similar to their comrades in Greece, did not only appreciate only the lyrics, but also the sound of the bouzouki, extensively used in Theodorakis' compositions, which they construed as profoundly moving. ${ }^{50}$ In spite of the fact that the lyrics did not directly address migration, performing Theodorakis' music in that context stressed the very territorial underpinnings of left-wing patriotism, which designated that Greeks could not be happy as long as they stayed away from their 'motherland'.51 Theodorakis himself attended some of those events, assigning meaning to them not only through his music, but also through his speeches. On 21 May 1965, when he visited the branch of the youth organisation of EDA in Munich, he highlighted the 'struggle to bring the migrants back to Greece'. ${ }^{52}$ In contrast with the bonds forged by singing Kazantzidis' songs, suffering was not an end in itself, but a prerequisite for militant action.

This particular enactment of kefi appeared in diverse cities in West Germany, where Greek migrants lived. It revolved around the onstage performance of these political songs by an artist, such as Petros Tsoupidis in Munich. ${ }^{53}$ Alternatively,

\footnotetext{
${ }^{50}$ About the approach of left-wingers in Greece towards the use of the bouzouki in the album Epitaphios, see: Papanikolaou, Singing Poets, 81f.

${ }^{51}$ The first compilation of songs, whose music was composed by Theodorakis and which explicitly addressed migration, appeared later on, in 1975 and was entitled 'Grammata ap' ti Germania' (Letters from Germany).

${ }^{52}$ Bulletin, DNL Munich and DNL Stuttgart, 21 May 1965. ASKI, Archeio EDA, 04/11.

${ }^{53}$ Invitation, DKNGL Munich, 1965. ASKI, Archeio EDA, 08/00001.
} 
choirs comprising DNL members sang those songs, such as at an event in Hamburg on 19 May $1965 .{ }^{54}$ When it came to entehno laiko, dancing was out of question. Still, the audience was not passive: the formation of the emotional community of Greek left-wing migrants involved collective singing, sometimes together with the artist performing Theodorakis' music. The reactions of the left-wingers were not homogeneous, however, but depended on different gendered expectations about how to express emotions. In all oral testimonies I have collected, it appears that men, in contrast with women, tried to refrain from crying in public, including when listening or singing along to such music. ${ }^{55}$ They seem to have tried to avoid behaviour patterns that would make them appear 'weak'. Despite such differentiations, left-wing men would seldom sing those entehno laiko songs individually, but, usually, jointly with other men and women, in order to reach kefi together. While anthropologist Catherine Lutz maintains that emotion is associated with femininity in the 'West', this does not apply in this case. ${ }^{56}$ One way or another, the performance of Theodorakis' music helped stir strong emotional ties among Greek left-wingers residing in West Germany regardless not only of their age, but also their gender.

\footnotetext{
${ }^{54}$ Announcement, DKNGL Hamburg, 10 May 1965. ASKI, Archeio EDA, 04/11.

${ }^{55}$ Until the 1960s, men in Greece were expected to act violently, especially when the reputation of their female relatives was supposed to be under threat. From that point onwards, however, aggression in interpersonal relationships came under fire in public debates. Still, this rhetoric did not necessarily lead to the elimination of such violence. See, for instance: Efi Avdela, Dia Logous timis: Via, Synaisthimata kai Axies sti metemfyliaki Ellada (Athens: Nefeli, 2002), 214-224. In any case, some left-wing Greek migrants in West Germany in the era under study still wished to avoid behaviour patterns that would make them seem 'weak'.

${ }^{56}$ Catherine Lutz, 'Emotion, Thought, and Estrangement: Emotion as a Cultural Category', Cultural Anthropology 1, 3 (1986), 287-309, here 287-289, 299-301.
} 


\section{Shifting political conditions in West Germany and Greece 'around 1968'}

While the 1960s witnessed the inception of an emotional community of left-wing migrants in West Germany, a series of events in the late 1960s and the early 1970s would have a profound impact on it.

Even before the 1960s, becoming a member of the left was not an uncomplicated process for Greek migrants. According to the Ausländergesetz or aliens law that was passed in 1965 , political activity on the part of migrants in general was not permitted if the activity was deemed incompatible with the principles of 'freedom' and 'democracy' as conceived by the West German state. ${ }^{57}$ If the latter decided that migrants overstepped the boundaries of legality with their militancy, they could face sanctions and even deportation. ${ }^{58}$ However, the condition of the Greek leftwingers deteriorated significantly in the late 1960s and the early 1970s. After the establishment of the dictatorial regime in 1967, travelling to Greece became more difficult for the advocates of the left, since the military junta had banned the activity of all parties and was persecuting dissidents. ${ }^{59}$ On top of that, it stripped many left-

57 'Das Ausländergesetz der Bundesrepublik Deutschland vom 28. Apr. 1965', available online at the website of the Zeitschrift für ausländisches öffentliches Recht und Völkerrecht (www.zaoerv.de; last visited: 17 Jun. 2013). About relevant debates among the strongest political parties in West Germany in the 1960s, see: Karen Schönwälder, Einwanderung und ethnische Pluralität. Politische Entscheidungen und öffentliche Debatten in Großbritannien und der Bundesrepublik von den 1950er bis zu den 1970er Jahren (Essen: Klartext 2001), 360f.

${ }^{58}$ About the surveillance of politicised migrants by the West German authorities in the 1950s, 1960s and 1970s, see Alexander Clarkson, Fragmented Fatherland: Immigration and Cold War Conflict in the Federal Republic of Germany, 1945-1980 (New York, Oxford: Berghahn 2010), 122.

${ }^{59}$ About the persecution of left-wingers in Greece by the dictatorship, see, for instance: Panourgia, Dangerous Citizens, 124-49. 
wingers of their Greek citizenship by cancelling their passports, while pro-junta Greek elements in the Federal Republic of Germany, such as the members of the Syndesmos Ellinon Dytikou Verolinou [League of Greeks of West Berlin], regularly intimidated foes of that regime. ${ }^{60}$ Conditions in West Germany also became increasingly unfavourable for left-wing militancy, especially on the part of 'foreigners' from the early 1970s on. As historian Quinn Slobodian notes, the government of West Germany 'expanded the scope of executive power greatly in its fight against left-wing terrorism' during this decade. As a result, whoever was regarded by the West German state as 'extremist' was bound to face legal sanctions. According to Slobodian, its reaction to the events of the 'German Autumn',61 in 1977 has so far been portrayed in relevant historiography as the culmination of this process. However, from the perspective of the rights of the 'foreigners' residing in West Germany, the peak of the expansion of 'the scope of executive power' coincided with the wave of deportations of 'foreign' radical militants in $1972 .^{62}$

Meanwhile, as briefly mentioned in the introduction, protest erupted in several locations around the globe 'around 1968'. Protests also swept West Germany at that

\footnotetext{
${ }^{60}$ The cancellation of the passports of left-wingers by the dictatorship was also lambasted, see Syllogos Ellinon Foititon kai Epistimonon, Deltio Kataggelias, West Berlin 1975 (source kept by Yannis Kallipolitis). About the aforementioned intimidation as well as the stance that West German political parties and trade unions kept, see Clarkson, Fragmented Fatherland, 120-150.

${ }^{61}$ The 'German Autumn' refers to the number of terrorist activities, such as the abduction and murder of Hanns-Martin Schleyer, President of the Confederation of German Employers’ Association, by the leftwing terrorist RAF (Rote Armee Fraktion, Red Army Fraction), as well as the suicide of the most prominent members of the RAF at the Stammheim prison.

${ }^{62}$ Quinn Slobodian, 'The Borders of the Rechtsstaat in the Arab Autumn: Deportation and Law in West Germany, 1972-73, German History 31, 2 (2013), 204-224, here 223f.
} 
point, in which the organisation SDS [Sozialistische Deutsche Studentenbund, Socialist German Student League], featured prominently. The SDS was founded in 1946 and was initially affiliated with the SPD [Sozialdemokratische Partei Deutschlands, Social Democratic Party of Germany], with which it severed ties in 1961. Protests escalated in 1967/68, when massive student demonstrations took place. However, the SDS soon experienced bitter infighting and divisions, before eventually disbanding in 1970. Collective action in West Germany was not limited to radical students at that point, however. From 1969 to 1972, the apprentices' movement [Lehrlingsbewegung] mobilised around ten thousand protestors, according to historian Knud Andresen. Nevertheless, the radical apprentices largely avoided representing themselves as '1968ers', since they equated the latter with students, whom they often viewed with scepticism. ${ }^{63}$ This tendency was not atypical among workers in West Germany during those years: for instance, functionaries of the union of metal workers (IG Metall) also treated radical students of the late 1960s with suspicion. ${ }^{64}$

Meanwhile, the protests that erupted in West Germany as in many other countries around the globe did not leave Greek migrants unaffected. The sites of their politicisation were multiple and not necessarily identical for workers and students. Greek left-wing students, such as Kostas Papanastasiou, joined teach-ins that the leftwing militants organised in 1968 against the Vietnam War. ${ }^{65}$ In the mean time, many

63 Knud Andresen, 'The West German Lehrlingsbewegung, 1969-1972. Why there is no "68er generation" of young workers', in Anna von der Goltz, ed., 'Talkin' 'bout my generation'. Conflicts of generation building and Europe's '1968' (Göttingen: Wallstein Verlag 2011), 216-229, here 216-20, 226-29.

${ }^{64}$ Ibid, 226-28.

${ }^{65}$ Interview with Kostas Papanastasiou, 13 Jan. 2013. Historian Belinda Davis also offers one of the few analyses that outline the activity of non-German students on several occasions 'around 1968'. See 
migrant workers participated in strikes. In one notable case in the Pierburg factory in Neuss during the summer 1973, Greek and Turkish workers played a major role. ${ }^{66}$ While their politicisation often stemmed from different sites, Greek left-wing migrant workers and students often mingled, especially in the Gemeinde halls. In contrast to West German militant workers and students that were active in this period, they did not necessarily view each other with suspicion, since they usually joined forces in their opposition to the authoritarian regime in Greece.

The establishment of the dictatorship in 1967 and the eruption of protests in West Germany in the late 1960s and early 1970s were factors that deeply affected the making of Greek left-wing migrants in the Federal Republic of Germany. Their political landscape altered fundamentally, witnessing a dialectic of convergence and

Belinda Davis, 'A Whole World Opening Up: Transcultural Contact, Difference, and the Politicization of "New Left" Activists', in Belinda Davis, Wilfried Mausbach, Martin Klimke and Carla MacDougall, eds., Changing the World, Changing Oneself. Political Protest and Collective Identities in West Germany and the U.S. in the 1960s and 1970s (New York, Oxford: Berghahn, 2010), 255-73.

${ }^{66}$ An interview of one of the protagonists of the strike, Anestis Kellidis, is the following: 'Gastarbeiter. $\begin{array}{llllll}\text { Mia } & \text { istoriki } & \text { apergia', } & \text { TVXS, } & 23 & \text { Aug. }\end{array}$ (http://tvxs.gr/news/\%CF\%84\%CE\%B1\%CE\%BE\%CE\%AF\%CE\%B4\%CE\%B9\%CE\%B1$\% \mathrm{CF} \% 83 \% \mathrm{CF} \% 84 \% \mathrm{CE} \% \mathrm{BF}-$ \%СF\%87\% CF\%81\%CF\%8C\%CE\%BD\%CE\%BF/\%CE\%B3\%CE\%BA\%CE\%B1\%CF\%83\%CF\%84 \% \%

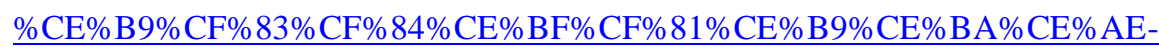
\%СE\%B1\%CF\%80\%CE\%B5\%CF\%81\%CE\%B3\%CE\%AF\%CE\%B1, last accessed: 7 Dec. 2013). Similarly, Turkish migrant workers figured prominently in the strike that erupted at that point in the factory of Ford in Cologne. See Jörg Huwer, 'Gastarbeiter' im Streik. Die Arbeitsniederlegung bei Ford Köln im August 1973 (DOMiD, Köln 2013). 
division: the increased efforts to co-ordinate a broad range of anti-dictatorial forces were often weakened due to their increasing fragmentation. In particular, centrist and left-wing groups often collaborated within the framework of the same anti-dictatorial committees, which spread throughout West Germany from 1967 onwards. ${ }^{67}$ Similarly, OEK [Omospondia Ellinikon Koinotiton, the Federation of Greek Communities] in West Germany, which had been established in 1966, was one more hotbed of the antidictatorial struggle. ${ }^{68}$ However, in the late 1960s and early 1970s, the Greek left became increasingly divided, which affected its activities in West Germany as well. The KKE suffered a split in 1968 into the pro-Soviet KKE and the KKE Esoterikou [Interior]. The latter gradually demanded greater autonomy from Moscow in terms of ideology. Numerous Greek migrants were members or sympathisers of those Communist parties. According to a 1974 report from the Federal Office for the Protection of the Constitution [Verfassungsschutz], a wide array of Greek associations in West Germany linked to 'orthodox' Communist organisations, namely KKE and KKE Esoterikou, attracted a declining, but significant number of members: 19,000 in $1971,14,000$ in 1973 and 9,150 in $1974 .{ }^{69}$ Meanwhile, a Greek Maoist group - the EKKE [Epanastatiko Kommounistiko Komma Elladas, Revolutionary Communist Party of Greece] - was formed in West Berlin in 1970. EKKE was mainly influential among Greek students living in that country. ${ }^{70}$ Other dissidents formed PAK

\footnotetext{
${ }^{67}$ See, for instance: Press Release, Second Congress of the Antidictatorial Committees in West Germany, Frankfurt am Main, Dec. 1968. ASKI, Archive of Giorgos Tsiakalos, K2.

${ }^{68}$ Decisions of the First Congress of OEK, 12-13 Feb. 1966. Archive of the OEK; Minutes of the discussion of the Administrative Council of OEK on 31 August-1 September 1968. Archive of the Greek Community in Cologne.

${ }^{69}$ Verfassungschutz ’74, Federal Ministry of Interior, Jul. 1975, 132-33. Author’s collection.

${ }^{70}$ Ibid, 134.
} 
[Panellinio Apeleytherotiko Kinima, Panhellenic Liberation Movement], an organisation that attracted left-wingers and liberals and which was mainly inspired by liberation movements in Latin America. ${ }^{71}$ PAK was active both in Greece and abroad, including several cities in West Germany. The Verfassungsschutz estimated the total membership of the Greek Maoist organisations and PAK in West Germany around 2200 and 1700 militants in 1973 and 1974, respectively. ${ }^{72}$ These left-wing groups, both in Greece and in the Greek migrant communities in West Germany, often engaged in bitter debates, with each claiming to represent the genuine and most effective version of 'antifascism' and 'anti-imperialism'. ${ }^{73}$ Greek centrist organisations were also active in West Germany at that point, such as EK-EDIN [Enosi Kentrou-Elliniki Dimokratiki Neolaia, Centre Union-Greek Democratic Youth], which established its own headquarters in Hanover.

Protests 'around 1968' in West Germany also provided numerous opportunities to those Greek left-wingers to collaborate with local activists. ${ }^{74}$ Such links were not a novelty of the late 1960s: for instance, young EDA members participated in the Ostermarsch [Easter marches for peace] in the early-to-mid 1960s

\footnotetext{
${ }^{71}$ Kostis Kornetis, 'Student Resistance to the Greek military dictatorship: Subjectivity, Memory, and Cultural Politics, 1967-1974', PhD thesis, European University Institute, Florence, 2006, 84.

${ }^{72}$ Verfassungschutz '74, 134.

${ }^{73}$ In contrast with the anti-dictatorial committees, the operation of the Greek Communist organisations was illegal in West Germany at that point.

${ }^{74}$ However, the collaboration between local and migrant left-wingers was not at all a given: quite notably, Turks and Germans initially struggled together during the Ford strike in Cologne in summer 1973, but such solidarity came soon to an end. See Huwer, 'Gastarbeiter' im Streik, 98. The extent to which local activists co-operated at that point with diverse groups of migrant protestors, including Greeks, Turks, Spaniards and Italians, certainly requires further examination.
} 
alongside local comrades of theirs. ${ }^{75}$ Still, while Greek migrant left-wingers continued to be staunch advocates of Greek patriotism and viewed themselves as temporarily residing in West Germany, their contacts with local activists intensified at that point. Soon after the coup d'état was staged, Greek left-wing migrant workers and students, together with local comrades of theirs as well as other migrants, organised numerous demonstrations throughout West Germany. Among those who participated were the sympathisers and members of a wide array of West German organisations, such as the SDS (until its demise in 1970), the Maoists and the Jusos (the youth organisation of the SPD at that point). In this vein, the KKE collaborated with the pro-Soviet and proGDR DKP [Deutsche Kommunistische Partei, German Communist Party], which was formed in 1968. For instance, when dissident students occupied the Athens Polytechnic in November 1973, the Maoists participated in marches against the dictatorship in many cities, such as Frankfurt, Göttingen and Bremen. ${ }^{76}$ Multiplying forms of such co-operation emerged at that point. For instance, local left-wingers, who were unknown to the Greek military junta, often travelled to Greece in order to smuggle material published by clandestine left-wing groups to their comrades in West Germany. ${ }^{77}$ Another development at that time was the joint initiatives formed by a diverse array of migrants against the authoritarian regimes in their countries of origin.

\footnotetext{
${ }^{75}$ Report, DKNGL Hamburg, 23 Jan. 1966. ASKI, Archeio EDA, 04/11.

${ }^{76}$ For a detailed list of such protest actions, please see the databank of the MAO [Materialien zur Analyse von Opposition, Material for the Analysis of the Opposition] Project and, particularly, the information accessible online in the following link: http://www.maoprojekt.de/INT/EU/GR/Griechenland.shtml (last visited: 19 Jun. 2013). Mao Project is run by Dietmar Kesten and Jürgen Schröder. This source includes material produced by radical left-wing groups in West Germany in the 1970s.

${ }^{77}$ See, for instance, interview with Kostas Papanastasiou, 13 Jan. 2013.
} 
Gortynos, who progressed from the EDA to the KKE Interior, emphasised the 'militant relationships' between left-wing Greeks and Spanish people in West Germany who opposed the Franco regime. ${ }^{78}$ In general, the perception that they were all 'suffering' brought left-wing militant migrants as well as locals closer, in their struggle to change political situation in their country of origin but also globally.

\section{7-1974: 'Going out in the rain' and overcoming fear}

Similar to the early-to-mid-1960s, left-wing militancy continued to be a bodily experience, one that was expressed in song and dance, among others, for Greek workers and students in West Germany after 1967. The developments 'around 1968' helped reshape the emotional community of Greek left-wing migrants, contributing to its expansion ${ }^{79}:$ Greek centrists and local left-wingers increasingly participated in the performances around which this community revolved.

In particular, the very conditions which Greek left-wing migrants in West Germany had to grapple with at this point further complicated their emotional experiences. Facing a repressive dictatorship at home and growing limitations abroad, they had to deal with additional dimensions of fear in comparison to the pre-1967 period: fear of not being able to return to their country of origin for a long time, or even worse, of being deported to Greece and subsequently imprisoned and tortured there. The very impossibility of remigration during those years exacerbated the 'suffering' they associated with their migrant status. The emotional condition of

\footnotetext{
${ }^{78}$ Interview with Stathis Gortynos, 28 Mar. 2013.

79 By expansion I mean that this emotional community included a broader spectrum of political activists. However, it is difficult to reach a definitive conclusion in terms of figures on whether more migrants participated in it in comparison to the pre-1967 era.
} 
Greek migrants aligned with other anti-junta organisations was similar. Fear seems to have prevented some Greek migrants from joining such groups, be they left-wing or centrist, as described by a text published by the left-leaning Greek community in Hamburg: 'Dictatorship beats up everyone who does not submit to its power. (...) However, not everybody is willing to be beaten up. If one's offspring [and/or] parents are in Greece (...) ${ }^{80}$

However, as in the early-to-mid 1960s, Theodorakis continued to inspire left wingers. Arrested by the regime, Theodorakis embodied resistance to it. $^{81}$ His messages, such as the one conveyed by Greek left-wingers in Düsseldorf, aimed at helping them show courage: 'The History of our Land is great and glorious. We have often struggled against well-armed enemies and we have defeated them (...) in the land where democracy was born tyrants die. ${ }^{82}$ Theodorakis' music was also touching for Greek left-wing migrants, as manifest in numerous oral testimonies. For example, Theodosia Karamanopoulou-Thielmann, a member of the KNE [Kommounistiki Neolaia Elladas, Communist Youth of Greece, the youth organisation of the proSoviet KKE], who lived near Leverkusen in the late 1960s, stated: 'I cannot forget

${ }^{80}$ Report on the activities of the Administrative Council of the (left-leaning) Greek Community of Hamburg, 1972. FZH, Gemeinde der Griechen in Hamburg e.V, 1970-76.

${ }^{81}$ Soon after the imposition of the dictatorial regime in 1967, he was rounded up. International solidarity initiatives developed subsequently. The dictatorship bowed to pressure, released him and permitted him to move to Paris, where he lived until the restoration of democracy in Greece. About the international solidarity initiatives, see, for instance, 'Geier von Lothringen’, Der Spiegel, 15 Jun. 1970, 106.

82 'Ellines patriotes, antifasistes-dimokrates', Proclamation, Leschi Filon tis EDA, Düsseldorf, 23 Apr. 1967. ASKI, Archeio Giorgou Tsiakalou. 'History' and 'Land' were capitalised in the original text. When EDA was banned in Greece, its members formed the Lesches Filon tis EDA [Clubs of the Friends of EDA] in West Germany. 
this, every Sunday my father listened to Radio Budapest, and suddenly he started shedding tears, he heard "be patient, the bells will soon ring", an extract from Romiossini, written by Ritsos and set to music by Theodorakis' ${ }^{83}$ KaramanopoulouThielmann recalled that this incident, which occurred during the dictatorship years, affected her deeply, contributing to her getting actively involved in politics - albeit not with PAK, which her father supported, but with the KNE. Her testimony suggests that politicisation in the so-called 'old left ${ }^{84}$ was not emotionally 'dull', confined to 'occasional demos, [and] sending small cheques to good causes', as historian and author David Caute has argued, but emotionally moving. ${ }^{85}$

However, a fundamental novelty of the junta period was that Theodorakis and his music took on meaning for all those who were opposed to the regime, not only for left-wingers. What constituted the basis of an emotional community of Greek leftwing migrants was transformed into one of all Greek migrants who despised the dictatorship. Even several centrists mentioned that they started listening to Theodorakis' music from 1967 onwards. Myrodis Athanassiou, a high-ranking cadre of the EK-EDIN in Munich in 1968-69 and in North Germany in 1971-74, stated that 'I started singing Theodorakis after 1967, often together with centrist, but sometimes also with left-wing friends of mine. (...) We sang those songs very frequently, wherever we could'. ${ }^{86}$ Gortynos also recounted that 'I sang Theodorakis' music

\footnotetext{
${ }^{83}$ Interview with Theodosia Karamanopoulou-Thielmann, 4 Feb. 2013.

${ }^{84}$ The term is often used in relevant scholarship in contradistinction to the 'new left'. I believe that the term 'old left' is mostly a value judgment that does not help scholars understand the ideas and the emotions of the members of such groups and, thus, I avoid using it.

${ }^{85}$ David Caute, The Year of the Barricades (New York: HarperCollins, 1988), 22.

${ }^{86}$ Interview with Myrodis Athanassiou, 24 Oct. 2013.
} 
alongside all Greeks who opposed the regime, not just the left-wing ones. ${ }^{, 87}$ This emotional community embraced left-wingers and centrists of all stripes, despite the growing tensions within those groups at that point. For those migrants, the performance of music served as a means of overcoming - or 'denigrating', to borrow Rosenwein's term, - the fear of expressing opposition to the dictatorial regime.

During these years, Theodorakis' work, which was banned in Greece, helped form what Benedict Anderson would call an 'imagined community' made up of Greek activists, living in Greece or abroad, who struggled against the military junta. These individuals did not necessarily know one another, but they repeated the same performances. ${ }^{88}$ The testimony of various militants, such as Athanassiou, is telling: 'Those songs made us feel strong, continuously, that we are not alone; we knew that all Greeks, a lot of Greeks sang those songs. ${ }^{89}$ However, the feeling of common belonging to this emotional community was also enacted by activists being in physical proximity with each other. Theodorakis' music played a key role in the performance of kefi within those Greek communities, where anti-dictatorship forces featured prominently, such as the Ekpolitistiki Koinotita [Cultural Community] in Munich as well as the one in Cologne. This involved activists gathering to sing collectively, in order to reach this emotional condition, which they linked with the desire to 'struggle'. That was evident, for instance, in an announcement from the Greek community in Cologne for an 'artistic event' featuring Theodorakis' music and

\footnotetext{
${ }^{87}$ Interview with Stathis Gortynos, 28 Mar. 2013.

${ }^{88}$ Benedict Anderson, Imagined Communities. Reflections on the Origins and Spread of Nationalism (London, New York: Verso 2006), $6 f$.

${ }^{89}$ Interview with Myrodis Athanassiou, 24 Oct. 2013.
} 
theatrical plays with explicitly anti-dictatorial content. The organisers hoped that 'deep emotions, kefi and enthusiasm' would prevail..$^{90}$

Taverns provided another context where Greek migrants who opposed the dictatorship gathered and sang collectively, choosing mainly entehno laiko composed by Theodorakis, and rizitika, Cretan folk songs which were re-discovered by the composer Yannis Markopoulos. Such activity had become widespread among dissident students in Greece at the time. According to historian Kostis Kornetis, 'the act of singing in the tavernas was the first testing ground in defying the authorities and a way of non-conformist socialisation', which amounted to nothing less than the 'cathartic energy of the taverna ritual'. 91 Those practices spread among Greek leftwing and centrist migrants in West Germany as well. According to historian Maren Möhring, Greek restaurants, which had first appeared in West Germany in the 1960s, acquired a broader clientele, including many locals, in the 1970 s and the 1980 s. ${ }^{92}$ One tavern that explicitly addressed politically active customers was Terzo Mondo [Third World], a West Berlin restaurant bought by the left-winger Kostas Papanastasiou in 1972. ${ }^{93}$ In a sense, Terzo Mondo epitomised the (trans)national orientation of the Greek left-wing migrants in the city. Dominating its interior decoration was a large poster of Ho Chi Minh that created a politicised context in which patrons engaged in

\footnotetext{
${ }^{90}$ Announcement, without date. Archive of the Greek Community in Cologne.

${ }^{91}$ Kornetis, 'Student Resistance', 250, 254.

${ }^{92}$ Möhring, Ausländische Gastronomie, 391.

${ }^{93}$ Greek taverns attracting politicised patrons were not a peculiarity of West Berlin. For instance, tavern Z-Sorbas in Göttingen labeled itself as a piece of 'Free Greece' during the dictatorship years. See, for instance: Göttinger Nachrichten, 5 Jun. 1972, 6, Mao Project, http://www.maoprojekt.de/BRD/NS/BRS/Goettingen_Auslaendergesetz.shtml (last visited: 10 Jul. 2013).
} 
discussions about the situation in Greece as well. ${ }^{94}$ Simultaneously, Theodorakis' music featured prominently in the tavern. In his oral testimony, Papanastasiou mentioned that he was not reluctant to sing those songs there: 'I had already gone out in the rain, I was not afraid of rain. (...) I was already convicted in Greece; I could not return' ${ }^{95}$ Normally, after having consumed copious quantities of red wine, the patrons also started singing. Those were typically large groups sitting at the same table(s). Asimatos stated that kefi was 'always an aspect' of those gatherings, adding that 'we needed it, especially since we experienced the echo of the persecution [of dissidents] by the dictatorship. (...) [kefi] was a breath, our life, what preserved [our identity] during those years when we could not [return to Greece]' ${ }^{96}$

The performance of kefi by migrants who opposed the Greek military junta transcended diverse barriers related to gender and age. It was a collective experience for men and women. In contrast to what Cowan describes about the enactment of this emotional condition in Sohos, left-wing Greek women in West Germany also consumed alcohol, while expressing their dedication to left-wing struggle through entehno laiko songs. In addition, Greek left-wing migrant students and workers, who might have been politicised in diverse settings in West Germany at that point, also took part in these performances of Theodorakis' entehno laiko music. Similar to the early-to-mid 1960s, those songs functioned as the bedrock of a transgenerational experience, which kept militants of differing age together.

The enactment of an emotional community centering on 'dedication to struggle' against the dictatorship in Greece also helped moderate political

\footnotetext{
${ }^{94}$ Interview with Kostas Papanastasiou, 13 Jan. 2013.

${ }^{95}$ Ibid.

${ }^{96}$ Interview with Grigoris Asimatos, 30 Jul. 2013.
} 
fragmentation and infighting among groups that opposed the dictatorship. Theodorakis' entehno laiko music stimulated all those dissidents, who often gathered in the same venues and were involved in the same performances described above. Although Papanastasiou was leaning towards the KKE Interior group at that point, his tavern attracted pro-Soviet Communists and Maoists as well. Quite tellingly, Aspasia Frangou, a student affiliated with EKKE in the early 1970s, stated: 'Kostas sang and gave us hope (...) ${ }^{97}$ Similarly, Apostolidis, a university student and KNE member in the 1970s, mentioned that 'Terzo Mondo attracted all progressive people. It was a Begriff [concept], ${ }^{98}$ The anti-dictatorship emotional community and its enactment through music were not split along party-political lines.

The performance of this emotional community of anti-dictatorship forces went hand in hand with the disruption of cultural events organised by pro-junta forces in West Germany by centrists and left-wingers. Indeed, culture functioned as a battleground between those forces: although the regime did not develop a coherent ideology, it embraced the slogan 'Fatherland, Religion, Family'. ${ }^{99}$ It claimed to represent the genuine expression of the Greek nation and thus sought to discredit the patriotic credentials of its opponents. Promoting cultural patterns, such as folk songs, which the dictators viewed as demonstrating the continuity of the Greek nation, featured prominently in the cultural events they organised both in Greece and in Greek consulates abroad. Such celebrations were held, for instance, on the anniversary of the War of Independence of 1821. In a somewhat contradictory

\footnotetext{
${ }^{97}$ Interview with Aspasia Frangou, 27 Mar. 2013.

${ }^{98}$ Interview with Nikitas Apostolidis, 15 Oct. 2012.

${ }^{99}$ Thanos Veremis, The Military in Greek Politics From Independence to Democracy (Montreal: Black Rose Books, 1997), 153.
} 
fashion, the authoritarian regime also promoted or, at least, tolerated Greek popular music artists, who were influenced by musical trends that emanated from Western Europe. Greek left-wing workers and students who resided in West Germany often stormed celebrations at the consulates and concerts by touring bands they viewed as sympathetic to the dictatorship. For instance, when the dictatorship sent an envoy to organise Easter celebrations in Hamburg in the late 1960s for the Greek migrants living there, the response of the Greek dissident migrants was prompt: During the event, many of the latter chanted slogans against the dictatorship and sang Theodorakis' music. ${ }^{100}$ This was not an isolated case: Such incidents occurred in other West German cities and towns as well, such as Sandbach. ${ }^{101}$ Opponents of the dictatorship viewed such disruption in emotional terms: As Papanastasiou put it, 'we spoiled their kefi'. ${ }^{102}$ The foes of the military junta not only wished to reach this emotional condition, but also to prevent their rivals from doing so.

\section{International solidarity and its complexities}

The growing 'international solidarity' among left-wing locals and migrants touched on above was not just expressed in statements and slogans, but was also enacted through music in many contexts. Singing was a core component of demonstrations and other gatherings against the dictatorship in Greece that were organised jointly by

\footnotetext{
${ }^{100}$ Iakovos Papadopoulos, correspondence, without date. FZH, Gemeinde der Griechen in Hamburg e.V 1965-69.

101 “'Wir haben unser Ziel erreicht!” Demokratische Griechen sprengten reigierungstreue Veranstaltung in Sandbach', Darmstädter Tagblatt, 24 Feb. 1969, 7. Archive of the DOMiD [Dokumentationszentrum und Museum über die Migration in Deutschland, Documentation Centre and Museum about Migration in Germany], Cologne.

${ }^{102}$ Interview with Kostas Papanastasiou, 13 Jan. 2013.
} 
Greek migrants and their local comrades. Such an event, for instance, took place on 22 March 1968 at the Max Emanuel Brauerei in West Berlin. Entitled 'Freedom for Greece', it featured Friedrich Hitzer, a translator of Russian literature into German, and Papanastasiou, who performed his own songs as well as Theodorakis' music composed. $^{103}$

During these years, Theodorakis' music witnessed growing popularity in West Germany. Local left-wingers were becoming increasingly acquainted with it: The DKP-leaning record label Pläne produced a record with his music in 1968, having translated the lyrics into German. ${ }^{104}$ His life and work was also presented in mainstream media, such as the magazine Der Spiegel and the main public television station ARD. ${ }^{105}$ The artist himself performed onstage on numerous occasions in West Germany shortly after his release and throughout the following decades. ${ }^{106}$ Those concerts attracted a mixed audience, comprising not only Greeks, but also locals. ${ }^{107}$

In the case of local and migrant activists, Theodorakis' music was an integral component in the mix of events organised by militants of the same ideological orientation, such as demonstrations held by the Maoists in Dortmund, West Berlin and other cities. Yet entehno laiko was not necessarily their sole feature. In the case of

${ }^{103}$ A poster of the event is available in: http://www.mao-projekt.de/INT/EU/GR/Griechenland.shtml (last visited: 4 Jul. 2013).

104 'Auf in den Kampf', Der Spiegel, 6 May 1968, 179.

${ }^{105}$ Relevant information can be found in 'Diese Woche im Fernsehen', Der Spiegel, 9 Apr. 1973, $191 \mathrm{f}$.

${ }^{106}$ For example, he performed at the Schauspielhaus in Hamburg on 17, 19 and 22 Dec., shortly after the collapse of the dictatorship. See Maria Adamantidou, Mikis Theodorakis. My posters (Athens: Kerkyra Publications, 2007), 160.

${ }^{107}$ See, for instance: Interview with Yannis Kastritis, 11 Nov. 2013. Kastritis was aligned with EKKE and student in West Berlin in the early 1970s. 
Dortmund, local and migrant protestors appear to have repeatedly sung the Internationale together, rendering their bonds palpable. ${ }^{108}$ However, such demarcation was not impenetrable: the intermingling of local and migrant militants of different ideological affiliations was not uncommon. The events surrounding May Day facilitated such interaction, for example. After the demonstrations finished, migrants and locals gathered at the Heime, where Greek workers stayed, as well as in student halls of residence, such as those in West Berlin and Munich. Apostolidis and Katsantonis stated that the occasion was a 'feast' [glenti]. Greek activists cooked and sold souvlaki. During these gatherings, and in a manner similar to the pre-1967 period, those migrants were involved in an interplay between two enactments of kefi: a broader one, which included listening and dancing to folk songs, as well as a narrower, politicised one that revolved around collective singing of Theodorakis' entehno laiko music.

These enactments were both transnational and national. During events that were dedicated to the major concern of Greek left-wing and centrist migrants at that point, the toppling of the Greek junta, they tackled with fear and felt hope by listening to music composed by Theodorakis together with local and other migrant comrades of theirs; on some occasions, as shown below in more detail, they also jointly sang those songs. Meanwhile, his music functioned for left-wing locals, at least those aligned to the SDAJ, as a (trans)national symbol that stirred emotions. While they labelled Theodorakis' music as 'Greek', they simultaneously construed it as an element of a transnational 'democratic' culture and, more importantly, as a genre, which would

108 'Dortmund: 15000 demonstrierten', Proletarischer Kurs, Oct. 1972, 13, Mao-Projekt, http://www.mao-projekt.de/BRD/NS/BRS/Goettingen_Auslaendergesetz.shtml (last visited: 4 Jul. 2013); Interview with Yannis Kastritis, 11 Nov. 2013. 
breed 'courage' to militants across national borders to confront an 'international alliance' of (extreme) right-wingers. ${ }^{109}$ However, the effort to establish transnational affective bonds through those songs did not always unfold smoothly. At least from the perspective of Greek left-wing and centrist migrants, listening to Theodorakis' music in the context under study reinforced national boundaries, since their local allies either did not manage or did not even try to emulate the ways in which the Greek militants performed. Asimatos stated that while the former were also 'emotionally moved' by Theodorakis' music and 'even tried to sing it', they did so 'clumsily', something that set them apart from the emotional performance of their Greek comrades. ${ }^{110}$ By contrast, Katsantonis claimed that 'we, Greeks, we sing our emotions', adding that his 'German comrades' just listened to Theodorakis' music without really reacting, not even reciting the verses they were familiar with. ${ }^{111}$ The opposition between emotionally expressive Greeks and more restrained Germans is a recurring theme in several oral testimonies I have gathered, regardless of whether the workers or students in question have henceforth re-emigrated to Greece or not. Some interviewees went further and described such differing emotional expressions in music performances as timeless characteristics of (national) cultures. Kostas Papadopoulos, a KNE member

\footnotetext{
${ }^{109}$ See, for instance, Werner Winter, 'Freiheit für Mikis', elan, Oct. 1968, 11. Moreover, Eckard Holler mentioned that he approached Theodorakis' music as a core component of a transnational 'alternative' and 'democratic' culture, whose forging was the aim particularly of cultural events he helped organise in the 1970s and the 1980s, such as the 12. Tübinger Festival in 1986. Interview with Eckard Holler, 12 Dec. 2013. Holler was affiliated with the SDAJ in the early 1970s. However, the issue whether members of other West German left-wing groups conceptualised and performed Theodorakis' music in the same way during the late 1960s and early 1970s requires further examination.

${ }^{110}$ Interview with Grigoris Asimatos, 30 Jul. 2013.

${ }^{111}$ Interview with Dimitris Katsantonis, 17 Feb. 2013.
} 
who studied in Bonn in the early 1980s before returning to Athens, maintained that 'we (the Greeks) speak loudly, laugh loudly, our relationship to our motherland is intense'. ${ }^{112}$ He stated that a similar situation could be observed in the early 1980s. The intensification of the arms race between the Cold War blocs triggered protests across the globe from the late 1970s onwards, which reached their apogee in the early-to-mid 1980s. ${ }^{113}$ Protest was widespread in West Germany as well. When some 300,000 people marched in Bonn in October 1981 against the deployment of Pershing and cruise missiles, Greek left-wing migrants also participated and thus practically expressed international solidarity. At the same time, however, Papadopoulos experienced music as a means of national demarcation: 'I remember a huge demonstration in Bonn (...) we were singing and dancing to slogans for six hours (...) the Greeks are loud, they want to make their presence felt' ${ }^{114}$

At least some Greek militant migrants, as these examples suggest, tended to reproduce a north-south distinction, according to which people from the south are more 'authentic' and 'direct' when expressing their feelings. ${ }^{115}$ Such purported 'authenticity' not only demarcated national boundaries in common performances, but

\footnotetext{
${ }^{112}$ Interview with Kostas Papadopoulos, 17 Dec. 2012.

${ }^{113}$ Lawrence S. Wittner, Towards Nuclear Abolition: A History of the World Nuclear Disarmament Movement, 1971 to the Present (Stanford: Stanford University Press 2003).

${ }^{114}$ Interview with Kostas Papadopoulos, 17 Dec. 2012.

${ }^{115}$ Such a perception was widespread in Greece and was not specific to left-wingers: according to anthropologist Regina Römhild, in encounters between locals and tourists from northern Europe in tourist resorts in Greece- at least in Crete, the former, 'especially men, would often stress their different, authentic and free way of life'. See Regina Römhild, 'Practised Imagination. Tracing Transnational Networks in Crete and Beyond', Anthropological Journal on European Cultures 11: Shifting Grounds. Experiments in Doing Fieldwork (2002), 159-190, here 170f.
} 
also inverted a north-south hierarchy by valorising the features that were associated with the latter. Still, such discrepancies in emotional expression did not prevent common action: even if they were more reserved, the local activists were described by their Greek comrades as feeling a genuine sense of solidarity for them and were thus deemed reliable allies.

While such ambiguities of the contact between left-wing Greek migrant and local activists continued from the mid-1970s to the 1980s, the period was also marked by significant transformations both in West Germany and Greece. At around that point, the second generation of Greek migrants began to emerge, a segment of which would later also get involved in politics. ${ }^{116}$ According to anthropologist Regina Römhild, who borrows an idea put forth by her colleague Sven Sauter, this second generation of Greek migrants established 'new connections apart from both their parents' culture and German culture'. ${ }^{117}$ Moreover, according to Rita Chin, from the late 1970s onwards, the West German state began to seriously consider the 'integration' of migrants. ${ }^{118}$

Meanwhile, a particularly important change for left-wingers occurred in Greece in 1974 with the collapse of the dictatorship: At that point, the foundations for a stable democracy were laid down in Greece, in which anticommunism no longer served as the official ideology; as a result, the Communist groups were legalised that

\footnotetext{
${ }^{116}$ The issue whether the so-called 'second-generation migrants' regarded themselves as migrants needs to be scrutinised.

117 Regina Römhild, 'Practised Imagination', 163; Sven Sauter, Wir sind 'Frankfurter Türken'. Adoleszente Ablösungsprozesse in der deutschen Einwanderungsgesellschaft (Frankfurt am Main: Brandes und Apsel, 2000).

${ }^{118}$ Chin, The Guest Worker Question, 10f.
} 
year. ${ }^{119}$ Communist and Socialist groups became very strong, especially in student societies. Similarly, left-wing organisations dominated the Greek communities and student societies in West Germany in the mid-to-late 1970s. ${ }^{120}$ The political situation in Greece posed a challenge for many Greek left-wing migrants in Germany: for some, such as Gortynos, it signaled the opportunity to return to Greece without the prospect of state persecution. ${ }^{121}$ Still, the decision of left-wing Greek migrants in West Germany to remigrate was not merely linked with their perceptions of political conditions in Greece. In numerous oral testimonies, getting married and having children in West Germany was experienced by many, male and female, as a turning point which impeded their remigration. ${ }^{122}$ Some, who remained, such as Karamanopoulou-Thielmann, began to distinguish between 'home' and 'motherland', associating Germany with the former and Greece with the latter. ${ }^{123}$ The impact of this confluence of factors in the making of Greek left-wing migrant identities in West Germany as well as the emotional investment of their everyday life, mark a rupture which requires further examination.

\section{Conclusion}

First-generation migrants in West Germany were not a silent group; as Bojadžijev and Goeke have demonstrated, a section of them was involved in politics. Greek migrants were no exception: many of them were affiliated with left-wing organisations and

\footnotetext{
${ }^{119}$ Voulgaris, I Ellada tis Metapolitefsis, 25-141.

120 'I PASP proti dynami sto exoteriko', Agonistis, 5 Jan. 1979, 2.

${ }^{121}$ Interview with Stathis Gortynos, 28 Mar. 2013.

${ }^{122}$ Interview with Nikitas Apostolidis, 15 Oct. 2012; interview with Kyriakos Georgarakos, 11 Feb. 2013.

${ }^{123}$ Interview with Theodosia Karamanopoulou-Thielmann, 4 Feb. 2013.
} 
were active in Greek communities and student societies throughout the 1960s and the 1970s. This article shows that the activity of those militant migrants was immersed in emotions. To appropriate a term introduced by Rosenwein, militant migrants were involved in overlapping emotional communities, which usually rested on, but sometimes also transcended, national and regional ties. The formation of those communities was linked with performances of music. Together with other groups of non-politicised Greek migrants, Greek left-wing migrants shared the feeling of 'suffering' involved in living away from their natal areas, which they particularly voiced by collectively singing Kazantzidis' sorrowful songs. Still, kefi was not absent from the practices of the national and regional emotional communities, in which they participated. It was a condition they reached especially by singing and dancing to folk music. Greek left-wing migrants developed a narrower emotional community in the early-to-mid 1960s, which revolved around the effort to transform 'suffering' into 'courage', hope and commitment to 'struggle'. Singing together entehno laiko music composed by Theodorakis in diverse contexts, such as the Heime, Greek community halls and taverns, helped create this community. The enactment of the latter did not remain static, but was seriously affected by a number of developments of the late 1960s and the early 1970s, most notably the establishment of the military junta in Greece in 1967 and the protests 'around 1968' in West Germany. At that point, this emotional community continued to revolve around Theodorakis' music, but it also branched out. It was transformed into one encompassing both left-wing and centrist opponents of the dictatorship. It featured as a gel that brought together Greek militant workers and students, who may have been politicised in different sites, as well as activists aligned in various organisations. From the late 1960s onwards, the same music genre also featured prominently in a growing number of events organised by 
left-wing migrants and locals. It accommodated the development of a community based on 'solidarity', which, to an extent, transcended national boundaries. However, the latter were not totally erased: some Greek left-wing migrants construed varying emotional expressions during such joint performances through national stereotypes; what emerged constituted a (trans)national emotional community. While Theodorakis' music was jointly performed by local and migrant militants, such enactment did not call the national identity of the Greek activists into question. 